\title{
О.В. Хандогіна
}

Харківський національний університет міського господарства імені О.М. Бекетова, Україна

\section{КЛАСТЕРНИЙ АНАЛІЗ РЕГІОНІВ УКРАЇНИ ЗА РІВНЕМ РОЗВИТКУ СИСТЕМИ УПРАВЛІННЯ ВІДХОДАМИ}

Проведено кластерний аналіз регіонів України за економічними, екологічними та соціальними показниками щьо характеризують регіональний економічний розвиток та розвиток сфери поводження $з$ відходами. Визначено три групи регіонів, які характеризуються подібними ознаками. Проведено дискримінантний аналіз, отримано класифікаџійні дискримінуючі функції для груп регіонів. Встановлено показники, які найбільше впливають на розподіл регіонів на кластери.

Ключові слова: тверді побутові відходи, регіональний розвиток, система управління відходами, кластерний аналіз, дискримінантний аналіз.

\section{Постановка проблеми}

Диспропорції в рівнях розвитку регіонів та окремих складових мають негативний вплив на розвиток держави в цілому та мають вивчатись для визначення державної та регіональної політики, яка б враховувала вказані особливості.

Враховуючи комплексність та складність процесів, на сучасному етапі розвитку системи управління відходами, використовуючи наявні показники, що характеризують ï стан, вкрай важко охарактеризувати місце окремого регіону, провести міжрегіональні порівняння та виокремити території зі схожими проблемами, а отже - i шляхами їх вирішення.

\section{Аналіз останніх досліджень і публікацій}

Теоретичні та прикладні аспекти застосування кластерного підходу для активізації регіонального розвитку вивчаються в роботах українських та зарубіжних вчених [1-4].

Окремі дослідники приділяють увагу вивченню екологічних показників для диференціації регіонів України, в тому числі в сфері поводження 3 відходами [5-7]. Так, В.Ю. Приходько досліджує районування території України, проте обмежується лише показниками щодо захоронення твердих побутових відходів (ТПВ). Бездухов О.А. використовує кластерний підхід для розподілу регіонів за кількістю утворення та накопичення відходів в межах однієї області.

Метою статті $є$ дослідження диференціації регіональних систем управління відходами 3 урахуванням комплексу економічних, екологічних та соціальних складників.

\section{Виклад основного матеріалу}

На нашу думку, найбільш показовими індикаторами стану розвитку системи управління відходами можуть слугувати такі індикатори: темпи розвитку сектора перероблення відходів $\left(\mathrm{X}_{1}\right)$, рівень роздільного збирання побутових відходів в населених пунктах $\left(\mathrm{X}_{2}\right)$, плата за захоронення ТПВ $\left(\mathrm{X}_{3}\right)$, рівень охоплення населення послугами зі збирання побутових відходів $\left(\mathrm{X}_{4}\right)$, загальна площа полігонів та звалищ $\left(\mathrm{X}_{5}\right)$, обсяг збирання ТПВ відходів $\left(\mathrm{X}_{6}\right)$, середній затверджений тариф на послуги $з$ поводження 3 відходами для населення $\left(\mathrm{X}_{7}\right)$, фінансування сфери поводження з побутовими відходами $\left(\mathrm{X}_{8}\right)$. Важливим показником соціальноекономічного розвитку регіонів України, який варто також включати в дослідження для розуміння загального стану розвитку територій, $\epsilon$ індекс людського розвитку $\left(\mathrm{X}_{9}\right)$, який обчислюється в залежності від рівня здоров'я, освіти та доходу населення.

Темпи розвитку сектора перероблення відходів, виражені у відсотковому відношенні перероблених відходів до вивезених за період 2015 - 2018 рр., характеризують наближеність методів поводження 3 відходами до прогресивних технологій. Рівень роздільного збирання відходів обчислено як відсоток населених пунктів, у яких впроваджується роздільне збирання до загальної кількості населених пунктів регіону. Плата за захоронення відходів відповідає середньому затвердженому тарифу на захоронення відходів для населення, грн./м³. Даний показник може виступати свого роду економічним інструментом обмеження потрапляння відходів на захоронення. Показник охоплення населення послугами 3 вивезення відходів опосередковано свідчить про рівень укладення договорів на 
вивезення відходів 3 мешканцями та залучення відходів до «формальної» системи управління. Загальна площа полігонів та звалищ характеризує навантаження на довкілля, спричинене використанням застарілих та неефективних методів поводження з відходами. Обсяг збирання побутових відходів відображає кількість відходів, які утворюються в регіоні та обліковуються під час провадження операцій поводження 3 ними. Фактично, це всі відходи, які потрапляють до «офіційної» системи управління. Для використання в роботі обсяг зібраних відходів розраховано на душу населення в регіоні. Тариф на послуги характеризує обсяги надходження коштів від населення. Іншим механізмом фінансового забезпечення системи управління 3 відходами $\epsilon$ фінансування $з$ державного та місцевого бюджетів. Даний показник також розраховано на душу населення в регіоні.

Джерелом даних слугувала офіційна інформація про стан сфери поводження з відходами та кількість населення, оприлюднена на сайтах Міністерства розвитку громад та територій i Державної служби статистики України [9-10].

Для дослідження впливу даних факторів на розвиток сфери управління твердими побутовими відходами, регіони України було класифіковано 3 використанням методів кластерного аналізу та проведено дискримінантний аналіз. Такий підхід дозволяє побудувати науково обгрунтовані класифікації, визначити внутрішні зв'язки між окремими об'єктами досліджуваної сукупності в умовах постійного збільшення та ускладнення потоків статистичних даних [8].

Кластеризація регіонів здійснювалась за методом k-середніх 3 використанням пакету STATISTICA.

Враховуючи значний розбіг значень у даних, для коректного визначення відстаней проводилась стандартизація показників для приведення змінних до одного діапазону значень.

Кластеризація методом k-середніх передбачає задання кількості кластерів, на які проводиться класифікація. В роботі проведено розподіл об'єктів (регіонів) на три кластери. Для перевірки гіпотези про однорідність кластерів використано процедуру багатовимірного дисперсійного аналізу ознак для 2 - 5 кластерів та визначено, що розбиття на три кластери є доцільним.

В результаті кластеризації отримано групи регіонів зі схожими ознаками (рис. 1).

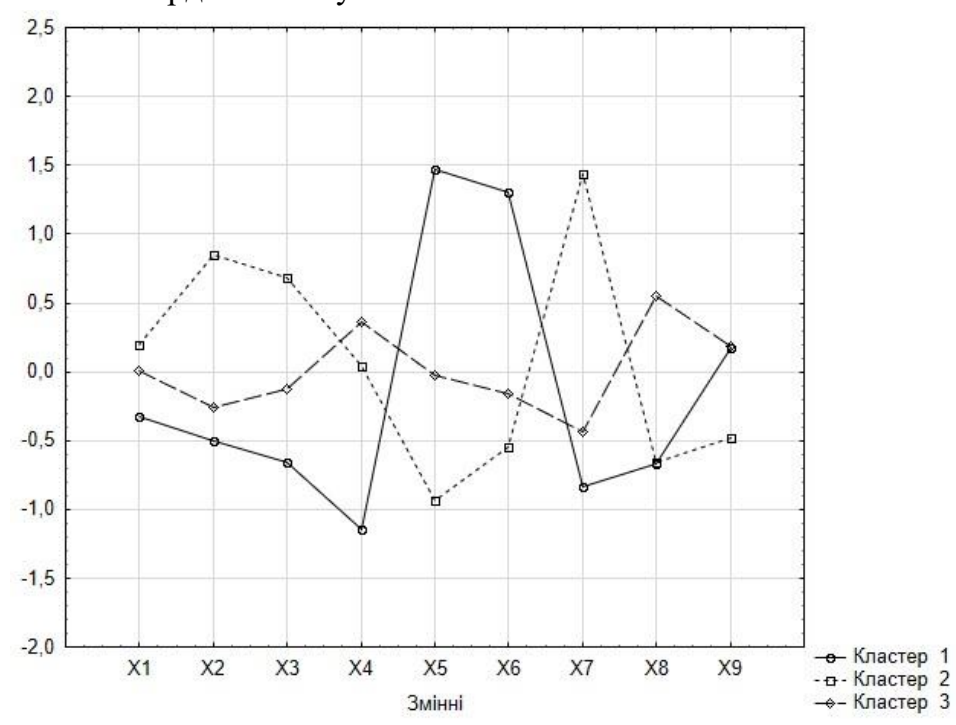

Рис. 1. Графік середніх для кожного кластеру

За результатами проведення кластеризації отримано три групи регіонів: до першої групи увійшло 4 області, до другої - 6, до третьої - 12 областей. Луганська, Донецька області та Автономна Республіка Крим не враховувались через відсутність даних для проведення аналізу.

В таблиці 1 наведені сформовані групи регіонів, а також усереднені значення досліджуваних показників за окремими кластерами.

Як видно з результатів аналізу, перший кластер характеризується найвищими обсягами збирання відходів, найбільшою площею полігонів та звалищ, найменшим відсотком охоплення населення послугами з вивезення ТПВ. Роздільне збирання та перероблення відходів знаходяться на найнижчому рівні розвитку, найнижчими є тарифи на здійснення операцій в сфері поводження з відходами. На нашу думку, дану групу можна охарактеризувати як регіони зі слабким рівнем розвитку системи управління відходами, значним антропогенним навантаженням. Дані області потребують впровадження широкого комплексу заходів для покращення ситуації. 
Другий кластер об'єднав регіони, для яких, основними характеристиками є: найнижчий рівень людського розвитку за найвищого середнього тарифу на поводження з відходами для населення. Тариф на захоронення відходів є найвищим (понад
36 грн/м³). Загальна площа полігонів та звалищ в цих регіонах $є$ найменшою з-посеред інших груп. Активніше за інші регіони впроваджуються сучасні технології поводження 3 відходами (роздільне збирання та перероблення).

Таблиця 1

Розподіл регіонів за кластерами та усереднені значення досліджуваних показників

\begin{tabular}{|c|c|c|c|c|}
\hline Кластер & Регіони & \multicolumn{3}{|c|}{ Середнє значення показників } \\
\hline 1 & $\begin{array}{l}\text { Дніпропетровська, } \\
\text { Житомирська, } \\
\text { Кіровоградська, Одеська }\end{array}$ & $\begin{array}{l}\mathrm{X}_{1}=-0,11 \% \\
\mathrm{X}_{2}=1,68 \% ; \\
\mathrm{X}_{3}=19,48 г \mathrm{pн} / \mathrm{m}^{3}\end{array}$ & $\begin{array}{l}\mathrm{X}_{4}=64,53 \% \\
\mathrm{X}_{5}=813,03 \text { га; } \\
\mathrm{X}_{6}=1,87 \mathrm{~m} / \text { рік на } 1 \text { люд.; }\end{array}$ & $\begin{array}{l}\mathrm{X}_{7}=64,82 \text { грн } / \mathrm{m}^{3 ;} \\
\mathrm{X}_{8}=9,68 г \mathrm{pн} / \mathrm{m}^{3} \\
\mathrm{X}_{9}=0,727\end{array}$ \\
\hline 2 & $\begin{array}{l}\text { Закарпатська, Івано- } \\
\text { Франківська, Львівська, } \\
\text { Тернопільська, Херсонська, } \\
\text { Черкаська }\end{array}$ & $\begin{array}{l}\mathrm{X}_{1}=2,5 \% \\
\mathrm{X}_{2}=10,89 \% ; \\
\mathrm{X}_{3}=36,48 \text { грн } / \mathrm{m}^{3}\end{array}$ & $\begin{array}{l}\mathrm{X}_{4}=77,28 \% \\
\mathrm{X}_{5}=132,33 \text { га; } \\
\mathrm{X}_{6}=0,94 \mathrm{~m}^{3} / \text { рік на } 1 \text { люд.; }\end{array}$ & $\begin{array}{l}\mathrm{X}_{7}=123,86 \Gamma \mathrm{pн} / \mathrm{m}^{3} \\
\mathrm{X}_{8}=9,85 \Gamma \mathrm{rн} / \mathrm{m}^{3} \\
\mathrm{X}_{9}=0,715\end{array}$ \\
\hline 3 & $\begin{array}{l}\text { Вінницька, Волинська, } \\
\text { Запорізька, Київська, } \\
\text { Миколаївська, Полтавська, } \\
\text { Рівненська, Сумська, } \\
\text { Харківська, Хмельницька, } \\
\text { Чернівецька, Чернігівська }\end{array}$ & $\begin{array}{l}X_{1}=-1,57 \% \\
X_{2}=3,32 \% ; \\
X_{3}=26,31 г \overline{г н} / \text { м }^{3}\end{array}$ & $\begin{array}{l}\mathrm{X}_{4}=80,7 \% \\
\mathrm{X}_{5}=390,83 \text { га; } \\
\mathrm{X}_{6}=1,13 \mathrm{~m}^{3} / \text { рік на } 1 \text { люд.; }\end{array}$ & $\begin{array}{l}X_{7}=75,24 \Gamma \mathrm{pн} / \mathrm{m}^{3} \\
\mathrm{X}_{8}=27,21 \Gamma \mathrm{pн} / \mathrm{m}^{3} \\
\mathrm{X}_{9}=0,728\end{array}$ \\
\hline
\end{tabular}

Для областей, що становлять третю групу, характерними є наступні ознаки: найбільший обсяг фінансування системи управління відходами при середніх тарифах на поводження 3 відходами, а також найвищий рівень надання послуг з вивезення побутових відходів, скорочення обсягів перероблення відходів.

Для визначення показників, які найкраще розділяють виявлені сукупності проведено дискримінантний аналіз.

Результати аналізу свідчать, що найбільше дискримінують регіони 5 показників: середній тариф на поводження 3 відходами для населення, фінансування сфери поводження з відходами, площа полігонів та звалищ, обсяг збирання відходів на душу населення, а також темпи розвитку сектора перероблення відходів. Це підтверджується також і перевіркою статистичної значимості дискримінуючих функцій (табл. 2) Побудована модель визначає розподіл регіонів на групи 3 точністю $100 \%$ на рівні значимості $\mathrm{p}<0,005$. Решта показників не були включені в модель через низьку значимість.

Основні статистики дискримінантного аналізу

Таблиця 2 Лямбда Уїлкса: ,03795 прибл. F (10,30)=12,400 p< ,0000

\begin{tabular}{|l|c|c|c|c|c|c|}
\hline \multicolumn{7}{|c|}{ Лямбда Уїлкса: ,03795 прибл. F (10,30)=12,400 p<,0000 } \\
\hline & $\begin{array}{c}\text { Уілкса } \\
\text { Лямбда }\end{array}$ & $\begin{array}{c}\text { Часткова } \\
\text { Лямбда }\end{array}$ & $\begin{array}{c}\text { F-виключ } \\
(2,15)\end{array}$ & p-рівень & Толер. & $\begin{array}{c}1 \text {-толер. - (R- } \\
\text { кв. })\end{array}$ \\
\hline $\begin{array}{l}\text { Середній тариф на } \\
\text { поводження з відходами для } \\
\text { населення }\end{array}$ & 0,151421 & 0,250626 & 22,42507 & 0,000031 & 0,783165 & 0,216835 \\
\hline Площа полігонів та звалищ & 0,055376 & 0,685314 & 3,44389 & 0,058772 & 0,934537 & 0,065463 \\
\hline $\begin{array}{l}\text { Фінансування сфери } \\
\text { поводження з відходами }\end{array}$ & 0,056473 & 0,672007 & 3,66060 & 0,050734 & 0,935510 & 0,064490 \\
\hline $\begin{array}{l}\text { Обсяг збирання відходів на } \\
\text { душу населення }\end{array}$ & 0,054896 & 0,691313 & 3,34893 & 0,062742 & 0,852402 & 0,147598 \\
\hline $\begin{array}{l}\text { Темпи розвитку сектора } \\
\text { перероблення відходів }\end{array}$ & 0,044877 & 0,845650 & 1,36892 & 0,284400 & 0,867000 & 0,133000 \\
\hline
\end{tabular}

За критерієм Хi-квадрат обидві дискримінантні функції $\epsilon$ статистично значущими. Кумулятивна частка дисперсії за першою функцією становить $0,87 \%$, тобто вона має більше дискримінуюче значення у порівнянні з другим коренем.

Функції класифікації регіонів України за показниками економічного, екологічного та соціального розвитку систем управління відходами можна представити у вигляді рівнянь (1-3), що являють собою лінійні функції ознак, які оптимально розділяють аналізовані регіони та $є$ статистично достовірними: 
для першого кластеру:

$$
F_{\text {cluster } 1}=-7,807 \cdot X_{7}+4,354 \cdot \mathrm{X}_{5}-2,28 \cdot \mathrm{X}_{8}+3,677 \cdot \mathrm{X}_{6}-1,791 \cdot \mathrm{X}_{1}-11,651
$$

для другого кластеру:

$$
F_{\text {cluster } 2}=10,516 \cdot X_{7}-2,118 \cdot \mathrm{X}_{5}-0,011 \cdot \mathrm{X}_{8}-2,762 \cdot \mathrm{X}_{6}+1,816 \cdot \mathrm{X}_{1}-10,782
$$

для третього кластеру:

$$
F_{\text {cluster } 3}=-2,656 \cdot X_{7}-0,392 \cdot \mathrm{X}_{5}+0,765 \cdot \mathrm{X}_{8}+0,155 \cdot \mathrm{X}_{6}-0,311 \cdot \mathrm{X}_{1}-1,39
$$

Результати дискримінантного аналізу дозволяють, по-перше, інтерпретувати відмінності між визначеними кластерами регіонів, по-друге проводити класифікацію нових об’єктів.

Результати розташування кластерів в дискримінантних осях наведені на графіку (рис. 2).
Всі кластери мають чітке розділення в канонічних дискримінантних осях, обраних таким чином, щоб найкраще відображати відмінності між групами об'єктів.

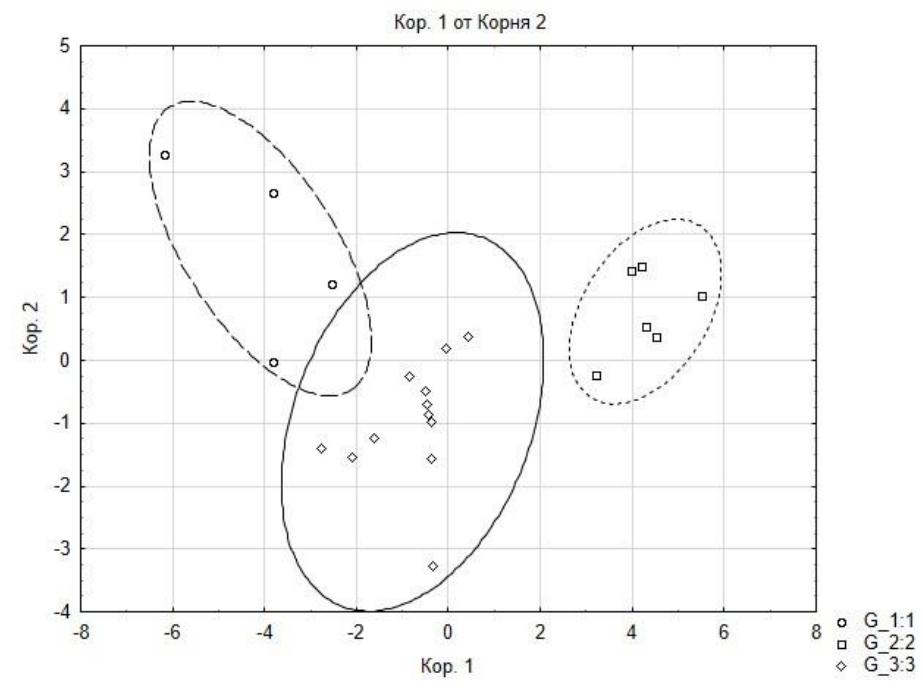

Рис. 2. Розташування кластерів в дискримінантних осях

\section{Висновки}

Запропонований підхід до вивчення особливостей регіонального розвитку систем управління побутовими відходами у контексті соціально-економічного розвитку та екологічної безпеки дає можливість ідентифікувати групи регіонів, що мають подібні сукупності ознак, за комплексом факторів. В результаті проведеного аналізу встановлено найбільш значущі індикатори регіонального розвитку систем управління відходами.

Результати кластеризації підкреслюють нерівномірність розвитку регіональних систем управління відходами та необхідність прийняття до уваги сукупності показників для формування загального уявлення про стан розвитку територій.

Кластерний підхід дозволяє класифікувати регіони України за вказаними показниками, а також розробляти диференційовані стратегії удосконалення системи управління відходами на регіональних рівнях, складати комплексні рейтинги розвитку систем управління відходами на регіональному рівні.

\section{Література}

1. Турський, I.В. Економетричний підхід до кластеризачії регіонів Украӥни за рівнем сочіальноекономічного розвитку [Текст] / І.В. Турський // Науковий вісник Ужгородського національного університету. Вип. 14, чacm. 2. 2017. - C. 147-152.

2. Brauksa, I. (2013). Use of Cluster Analysis in Exploring Economic Indicator Differences among Regions: The Case of Latvia. Journal of Economics. Business and Management, 1, 42-45.

3. Рядно, О.А. Дослідження структури та динаміки диференціації сочіально-економічного розвитку регіонів України на основі кластерного аналізу [Текст] / О.А. Рядно, О.В. Беркут // Економічний вісник Донбасу. - № 1 (43). $-2016 .-$ C. 60-67.

4. C.Yin, C. Feng, X. Ren, J. Yang and W. Cheng (2019). Research on Economic Development Level of Western Provinces in China Based on Cluster Analysis. 2019 4th International Conference on Mechanical, Control and Computer Engineering (ICMCCE), Hohhot, China, 64-643. doi: 10.1109/ICMCCE48743.2019.00023

5. Приходько, В.Ю. Дослідження регіональних особливостей захоронення твердих побутових відходів в Україні [Текст] / В.Ю. Приходько // Вісник ХНУ імені В. Н. Каразіна. - Вип. 21. - 2019. - С. 51-62. 
6. Бездухов, О.А. Кластерний підхід до дослідження динаміки накопичення та розподілу твердих побутових відходів (на прикладі Чернігівської області) [Текст] / O. А. Бездухов // Науковий вісник Херсонського державного університету. - Bun. 11. - 2019. - C.81-87.

7. Балуєва, О.В. Кластерний аналіз територій України за показниками антропогенних навантажень на навколишнє природне середовище [Електронний ресурс] / О.В. Бадуєва, Н.М. Чинкуляк // Ефективна економіка $\begin{array}{lllll}\text { № 12, } 2013 . & - & \text { Режим доступу }\end{array}$ http://www.economy.nayka.com.ua/?op $=1 \& z=2574$

8. Многомерный статистический анализ в экономике [Текст] : Учеб. пособие для вузов; ред. проф. Тамашевича. - М.: ЮНИТИ-ДАНА, 1999. - 598 c.

9. Стан сфери поводження з побутовими відходами в Украйні у 2015-2018 p. [Електронний ресурс] // Міністерство розвитку громад та територій Украйни: Режим достуny: http://www.minregion.gov.ual napryamkidiyalnosti/zhkh/terretory

10. Регіональна статистика [Електронний ресурс] // Державна служба статистики Украӥни. - Режим docmyny: http://www.ukrstat.gov.ual

\section{References}

1. Turskyj, I. V. (2017). Econometric approach to Ukraine's regions clusterization on the social-economic development level. Scientific Bulletin of Uzhgorod National University, 142, 147-152.

2. Brauksa, I. (2013). Use of Cluster Analysis in Exploring Economic Indicator Differences among Regions: The Case of Latvia. Journal of Economics. Business and Management, 1, 42-45.

3. Ryadno, O., Berkut, O. (2016). A study of the structure and dynamics of differentiation of social and economic development of Ukraine based on a cluster analysis. Economic Bulletin of Donbass, 1 (43), 60-67.

4. C.Yin, C. Feng, X. Ren, J. Yang and W. Cheng (2019). Research on Economic Development Level of Western Provinces in China Based on Cluster Analysis. 2019 4th
International Conference on Mechanical, Control and Computer Engineering (ICMCCE), Hohhot, China, 64-643. doi: 10.1109/ICMCCE48743.2019.00023

5. Prykhodko, V. Yu. (2019). Regional features research of Municipal Solid Waste Disposal in Ukraine. Bulletin of V.N. Karasin University, 21, 51-62.

6. Bezdukhov, O.A. (2019). Cluster approach to studying the current state of accumulation and spatial distribution of solid household waste (on the example of Chernihiv region). Scientific Bulletin of Kherson State University, 11, 81-87.

7. Balueva, O.V., Chynkulyak, N.M. (2013). Cluster analyses of the Ukrainian territories according to the indices of the anthropogenic loads on the natural environment. Efficient Economy, $12 . \quad$ Retrieved from http://www.economy.nayka.com.ua/?op=1\&z=2574

8. Mnohomernyi statystycheskyi analyz $\mathrm{v}$ ekonomyke (1999). M.: YuNYTY-DANA. 598.

9. State of domestic waste management sphere in Ukraine for 2015-2018. (2018). Ministry of Regional Development, Construction and Housing and Communal Services of Ukraine Retrieved from http://www.minregion.gov.ua/napryamkidiyalnosti/zhkh/terretory

10. Regional statistics (2018). State Statistics Service of Ukraine Retrieved from: http://www.ukrstat.gov.ua/.

Рецензент: д-р екон. наук, доц., завідувач кафедри туризму і готельного господарства Л.В. Оболєнцева, Харківський національний університет міського господарства імені О. М. Бекетова, Харків, Україна

\author{
Автор: ХАНДОГІНА Ольга Вадимівна \\ стариий викладач кафедри інженерної екологї \\ мiсm \\ Харківський національний університет міського \\ господарства імені О. М. Бекетова \\ E-mail-ol.khandogina@gmail.com \\ ID ORCID: http://orcid.org/0000-0002-1100-5267
}

\title{
CLUSTER ANALYSIS OF THE UKRAINE REGIONS ON THE LEVEL OF WASTE MANAGEMENT SYSTEM DEVELOPMENT
}

\author{
O. Khandogina
}

O.M. Beketov National University of Urban Economy in Kharkiv, Ukraine

The cluster analysis of the regions of Ukraine by economic, environmental and social indicators characterizing regional economic development and development of the waste management system is carried out in the paper. Three groups of regions characterized by similar features are identified. The average values of the studied indicators by separate clusters are determined. It was established, for example, that the regions from the first cluster are characterized by a low level of the waste management system development, in the regions from the second group modern technologies of waste management is more actively introducing in comparison with other regions. Discriminant analysis was conducted. The results of the analysis show that regions are differentiated mostly by five indicators: average tariff for waste management for the population, financing of waste management system, area of landfills and damps, amount of waste collection per capita, the rate of waste recycling sector development. The developed model determines the distribution of regions into groups with an accuracy of $100 \%$ at the significance level $p<0.005$. Classification discriminatory functions were obtained for groups of regions. The indicators influenced the distribution of regions into clusters are established. The results of the analysis highlight the irregularity of regional waste management systems development. The cluster approach allows classifying regions of Ukraine according to complex of indicators. Differentiated strategies for improving the waste management system at regional level as well as comprehensive ratings of the regional waste management systems development could be developed on the basis of such analysis.

Keywords: municipal solid waste, regional development, waste management system, cluster analysis, discriminant analysis. 